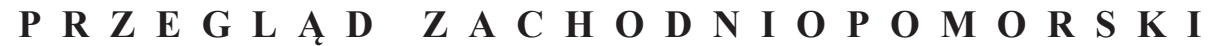 ROCZNIK XXXI (LX) ROK 2016 ZESZYT 1
}

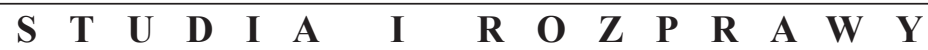

\author{
AgNieszKa Gut
}

Uniwersytet Szczeciński

\section{RYTM PRACY W KANCELARII KSIĘCIA WSCHODNIOPOMORSKIEGO, MściwoJa II (1266-1294)}

Słowa kluczowe: Pomorze Wschodnie, dyplomatyka, średniowieczne kancelarie Keywords: East Pomerania, diplomatic(s), Medieval chancelleries

\section{Uwagi wstępne}

Rytm pracy średniowiecznej kancelarii nie jest zagadnieniem, które pojawia się szczególnie często w kwestionariuszu polskich badań z zakresu dyplomatyki. Można nawet powiedzieć, że ugruntowana w historiografii teza o permanentnym (stałym) działaniu kancelarii władcy w średniowieczu, powodowała rezygnację z zajmowania się tą problematyką, zwłaszcza przy niewielkiej ilości dokumentów wystawianych przez książąt w XIII wieku. Pojawiały się jednak w literaturze głosy o wpływie pewnych zjawisk sezonowych (zima, żniwa) na rytm prac kancelaryjnych, które nie zostały podjęte w badaniach analitycznych ${ }^{1}$. Jedynym znanym mi badaczem, który dokonał takiej analizy na gruncie czeskiego dokumentu władcy końca XIII i początku XIV wieku, jest Ivan Hlavaček² ${ }^{2}$ Doszedł on

${ }^{1}$ W. Korta, Glos $w$ dyskusji, w: Problemy nauk pomocniczych historii, t. 5, Katowice 1976, s. 222; J. Bieniak, Gtos w dyskusji, w: tamże, s. 224.

${ }^{2}$ I. Hlavaček, Zur Frage der Saisonalität und des Arbeitsrhythmus in der mittelalterlichen Verwaltung. Bemerkungen zur Auslaufstatistik der Kanzleien der letzten Přemysliden und Johanns von Luxemburg, w: Homines et societas. Czasy Piastów i Jagiellonów. Studia historyczne ofiarowane Antoniemu Gąsiorowskiemu w 65. rocznicę urodzin, red. T. Jasiński, T. Jurek, J.M. Piskorski, Poznań 1997, s. 447-455. 
jednak do wniosku, że choć rzeczywiście istniały okresy większej lub mniejszej aktywności kancelarii, to nie wynikały one $\mathrm{z}$ wahań sezonowych³ ${ }^{3}$.

Mimo obserwacji I. Hlavačka (opartych częściowo na niepełnych danych), w niniejszym artykule zdecydowano się powrócić do tego niepopularnego zagadnienia, dokonując analizy rytmu pracy kancelaryjnej na dworze księcia wschodniopomorskiego, Mściwoja II, panującego w latach 1266-1294. Wybór kancelarii wynikał po pierwsze z faktu, że w ostatnim czasie autorka dokonała szczegółowego badania całości dyplomatyki wschodniopomorskiej do początków XIV wieku, w związku z czym znany jest przebieg procesu wprowadzania dokumentowej piśmienności pragmatycznej na tym obszarze 4 . Po drugie, ilość dokumentów wystawionych w okresie panowania Mściwoja była na tyle duża, że sytuuje go w grupie najbardziej aktywnych pod względem dyplomatyki książąt polskich II poł. XIII wiekus. Pozwala to na dokonanie obserwacji rytmu pracy kancelaryjnej, wykluczającej zwykły przypadek jako jedyną przyczynę jej wahań.

Przy analizie starano się zwrócić uwagę na trzy zasadnicze zagadnienia, mianowicie na cykle roczne, na rytm pracy w ciągu roku oraz w ciągu tygodnia. Przy obserwacji rocznej ilości dokumentów próbowano wyjaśnić przyczyny niewielkiej aktywności kancelaryjnej w początkowym okresie panowania Mściwoja II oraz ponadprzeciętne jej wzrosty po 1273 roku, kiedy już regularnie w każdym roku wystawianych było po kilka dokumentów. Przyczyn tych zjawisk upatrywano przy tym głównie w wydarzeniach politycznych. W przypadku natomiast rytmu w ciągu roku i w ciągu tygodnia starano się wyodrębnić wahania sezonowe. Ze względu na niewielką ilość danych nie wykorzystano przy tym statystycznej metody badań sezonowości, ograniczając się do procentowego zestawienia częstotliwości wystawiania dokumentów w poszczególnych miesiącach i dniach tygodnia. Analizując sezonowość roczną, zwrócono przede wszystkim uwagę na wpływ pór roku oraz na rytm roku liturgicznego z jego okresami zwykłymi i świątecznymi, okresem Adwentu i Wielkiego Postu, świętami nakazanymi, ruchomymi i nieruchomymi. Podobnie w przypadku sezonowości tygodniowej, przy badaniu której starano się zaobserwować najczęściej występujące dni ze szczególnym jednak uwzględnieniem roli niedzieli - dnia Pańskiego - jako

\footnotetext{
${ }^{3}$ Tamże, s. 455.

${ }^{4}$ A. Gut, Średniowieczna dyplomatyka wschodniopomorska. Dokumenty i kancelarie Pomorza Wschodniego do 1309 roku, Szczecin 2014.

${ }^{5}$ Tamże, s. 77, przypis 77.
} 
dnia wystawiania dokumentów. Wyniki analizy wahań sezonowych porównano przy tym do tych samych zjawisk w kancelarii wielkopolskiej Przemysła II i zachodniopomorskiej Bogusława IV ${ }^{6}$ w celu ustalenia, czy sezonowość w kancelarii wschodniopomorskiej była cechą typową dla końca XIII wieku, czy też była efektem indywidualnych zwyczajów dworu Mściwoja II.

Podstawę źródłową pracy stanowi 145 dokumentów Mściwoja $\mathrm{II}^{7}$, które w monografii pt. Średniowieczna dyplomatyka wschodniopomorska... zostały uznane przez autorkę za autentyczne lub za falsyfikaty powstałe w oparciu $\mathrm{o}$ istniejące i zaginione oryginały ${ }^{8}$. W analizie cyklu rocznego uwzględniono również dokumenty pozbawione datacji, których rok wystawienia został jednak w literaturze ustalony ${ }^{9}$, oraz dokumenty spisane później niż czas określony w formule datacyjnej, których czas wystawienia można bliżej określić ${ }^{10}$. Tych ostatnich - choć posiadają pełną datację - nie wykorzystano jednak do analizy sezonowości w ciągu roku i tygodnia, wychodząc z założenia, że czas oznaczony

${ }^{6}$ W tym przypadku tylko z lat 1278-1295, choć książę panował do 1309 r. W 1295 r. nastąpił jednak podział księstwa pomorskiego na dwie dzielnice i szczecińska część znalazła się w rękach młodszego brata Bogusława, Ottona I.

${ }^{7}$ Pommerellisches Urkundenbuch, hrsg. v. M. Perlbach, Danzig 1882 (dalej: PllUB); J. Zdrenka, Nieznany dokument Mściwoja II z roku 1274?, w: Personae, colligationes, facta. Profesorowi Kazimierzowi Jasińskiemu w 70. rocznice urodzin przyjaciele, koledzy, uczniowie, red. J. Bieniak i in., Toruń 1991, s. 283-284 (dalej: Zdrenka); K. Zielińska, Przywilej Mszczuja II z 1277 r. dla kasztelana puckiego Czcibora, Zeszyty Naukowe UMK w Toruniu, Nauki Humanistyczno-Społeczne, z. 354, Historia V, 1969, s. 16-19 (dalej: Zielińska).

${ }^{8} \mathrm{~W}$ tym drugim przypadku chodzi o dokumenty opublikowane w PllUB, nr 381, 505. Zob. A. Gut, Średniowieczna dyplomatyka..., Aneks I, nr 46, 53.

${ }^{9}$ PllUB, nr 250 (1271 r.), 251 (1271 r.). Zob. K. Jasiński, List Mściwoja II do margrabiów brandenburskich. Uwagi polemiczne i postulaty badawcze, w: Pomerania Mediaevalis. Pomorze stowiańskie i jego sasiedzi X-XV wiek, red. J. Hauziński, Gdańsk 1995; tenże, Wojna domowa na Pomorzu Gdańskim w latach 1269/70-1272 (ze szczególnym uwzględnieniem roli rycerstwa i możnowładztwa), w: Społeczeństwo Polski Średniowiecznej, t. 3, red. S.K. Kuczyński, Warszawa 1985, s. 146-158; J. Spors, Podziały administracyjne Pomorza Gdańskiego i Sławieńsko-Stupskiego od XII do poczatku XIV w., Słupsk 1983, s. 291-293. Inaczej B. Śliwiński, Rola polityczna możnowładztwa na Pomorzu Gdańskim w czasach Mściwoja II, Zeszyty Naukowe Uniwersytetu Gdańskiego, Rozprawy i monografie, nr 86, Gdańsk 1987, s. 89-102; PllUB, nr 284, 292, 475.

${ }^{10}$ PlIUB, nr 260 (1276 r.), 286 (1277 r.), 313 (1290 r.). Zob. B. Śliwiński, Pierwszy przywilej rycerski księcia Mściwoja II. Krytyka autentyczności dokumentu z roku 1266 dla Ścibora z Gacek, „Studia Źródłoznawcze”, XXXII-XXXIII, 1990, s. 179, 181; H. Lingenberg, Urkundenfälschungen des Klosters Oliva und anderer geistlicher Institutionen Pommerellens/Pommerns (bis ca. 1310), Lübeck 1996, s. 288-289; A. Gut, Średniowieczna dyplomatyka ..., s. 27-28; taż, Falsyfikaty pelplińskie do 1309 r., w: Kaci, święci, templariusze, red. B. Śliwiński, Malbork 2008 (Studia z dziejów średniowiecza, 14), s. 102-105; K. Bruski, Ziemie nad dolna Wierzyca od XIII do początku XV wieku, Gdańsk 1997, s. 53. 
w dokumencie odnosi się do czynności prawnej. We wszystkich pozostałych dokumentach - z powodu braku wyraźnych wskazówek na to, do którego momentu odnosi się data - datację potraktowano jako czas spisania dyplomu. Nie brano także pod uwagę tzw. kancelaryjności analizowanych dokumentów, wychodząc z założenia, że pisarze kancelarii Mściwoja II brali udział w przygotowywaniu zarówno tzw. dokumentów wystawcy, jak i odbiorcy, chociażby poprzez przywieszenie do nich książęcej pieczęci.

\section{Cykle roczne}

Roczna częstotliwość wystawiania dokumentów Mściwoja II (wykres 1) przedstawia się na dosyć jednolitym poziomie. Jedynie początkowo, do 1273 roku, obserwować można lata, w których w ogóle nie wystawiono dokumentu albo było ich bardzo mało (1-3). Od 1273 roku dosyć regularnie w imieniu księcia wystawiano od 4 do 7 dokumentów rocznie. Mniej dokumentów wydano jedynie w 1278 roku, natomiast zdecydowanie więcej w latach 1282-1284, 1290 i 1294.

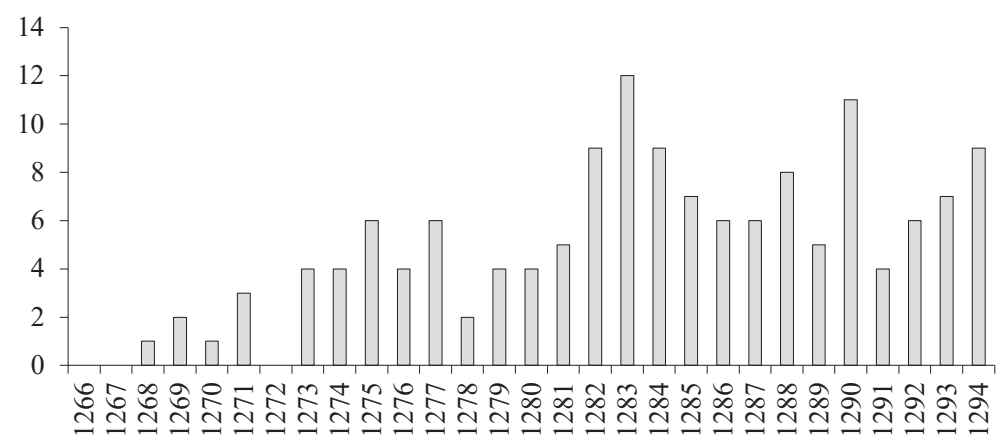

Wykres 1. Liczba dokumentów Mściwoja II w poszczególnych latach

Jak zauważono wyżej, najmniej dokumentów książęcych powstało w początkowym okresie panowania Mściwoja II, w latach 1266-1272 ${ }^{11}$. Ta ograniczona działalność kancelaryjna wynika z dwóch zasadniczych powodów. Po pierwsze, wpływała na to sama ogólna kondycja wschodniopomorskiej dyplomatyki

${ }^{11}$ PllUB, nr 225, 238, 239, 245, 248, 250, 251. Zob. A. Gut, Średniowieczna dyplomatyka wschodniopomorska.., s. 75, przypis 73 . 
w okresie poprzedzającym panowanie Mściwoja II. Ojciec księcia, Świętopełk - jak się wydaje - nie był jeszcze szczególnie zainteresowany rozwojem dyplomatycznej piśmienności pragmatycznej. Wystawił zaledwie 36 dokumentów, przy czym istniały długie okresy w czasie jego panowania, kiedy tych dokumentów nie było w ogóle. W latach 1260-1265 w skali rocznej władca ten wystawiał 1-2 dokumenty ${ }^{12}$. Większość dokumentów zredagowanych i spisanych na jego dworze stanowiły listy i mandaty, pisarze byli kapelanami, którzy tylko przygodnie zajmowali się książęcą korespondencją ${ }^{13}$. Wydaje się zatem, że w początkach panowania Mściwoja II nie było jeszcze wyrobionego zwyczaju potwierdzania czynności prawnych na piśmie i taką praktykę odziedziczył po ojcu jego następca.

Drugą grupę powodów niewielkiej częstotliwości wystawiania dokumentów przez Mściwoja II na przełomie lat 60. i 70. XIII wieku stanowią natomiast przyczyny polityczne. Mściwój bowiem w 1266 roku otrzymał we władanie jedynie część spadku po ojcu - dzielnicę świecką. Główną dzielnicę państwa - gdańską wraz z ziemiami słupską i sławieńską dostał natomiast jego młodszy brat - Warcisław $\mathrm{II}^{14}$. W efekcie takiego podziału poza zasięgiem władzy Mściwoja znalazły się najbardziej do tej pory zainteresowane dokumentem klasztory cysterskie w Bukowie i Oliwie oraz norbertanek w Żukowie ${ }^{15}$. Na małą ilość wystawionych dokumentów wpływ miała także sytuacja polityczna. Chronologia wydarzeń, które nastąpiły między rokiem 1266 a 1273, wzbudza wśród historyków wątpliwości. Niewątpliwie jednak okres ten był dla księstw wschodniopomorskich czasem niespokojnym. Jak zgodnie uznaje historiografia, Mściwój II od początku swego panowania dążył bowiem do przejęcia władzy nad całym dziedzictwem swego ojca, w efekcie czego w 1269 roku doszło do wybuchu wojny domowej pomiędzy księciem świeckim a jego bratem, Warcisławem. Z działaniami z lat 1269-1271 wiążą się również kolejne wydarzenia polityczne - najpierw udział Mściwoja w wojnie wielkopolsko-kujawskiej, potem najazd krzyżacki na ziemię tczewską, a w końcu agresja brandenburska na Pomorze powiązana z zajęciem

\footnotetext{
12 Tamże, s. 67-68.

13 Tamże, s. 118-119, 229-230.

${ }^{14}$ B. Śliwiński, Układ księcia wschodniopomorskiego Mściwoja II z margrabiami brandenburskimi w Choszcznie w 1269 r. Powrót problemu, w: Mieszczanie, wasale, zakonnicy, red. B. Śliwiński, Malbork 2004 (Studia z dziejów średniowiecza, 10), s. 271, literatura w przypisie 9.
}

${ }^{15}$ A. Gut, Średniowieczna dyplomatyka wschodniopomorska..., s. 214-218. 
Gdańska ${ }^{16}$. W 1272 roku Mściwój II wyszedł zwycięsko z tego politycznego zamieszczania, przejmując władzę nad całym księstwem wschodniopomorskim. Warcisław II zmarł bowiem w czasie wojny domowej, a Sambor II pozostał na wygnaniu, z którego nie udało mu się już powrócić. W porządkowaniu sytuacji wewnętrznej w księstwie i w karaniu niepokornych rycerzy i mieszczan w 1272 roku książę obchodził się doskonale jeszcze bez pomocy pisma.

Warto także zauważyć, że niemal wszystkie dokumenty wystawione przez Mściwoja II w latach 1266-1272 miały charakter polityczny. Były to bowiem układy zawierane z księciem szczecińskim, Barnimem I, z margrabiami brandenburskimi i krzyżakami ${ }^{17}$. Po wygnaniu Sambora II powstał z kolei dokument dla Tczewa, w którym zwycięski Mściwój obiecywał miastu te same swobody, które posiadał Gdańsk ${ }^{18}$. Polityczny charakter miała nawet generalna konfirmacja dla cystersów z Bukowa wystawiona w 1269 roku, w momencie, kiedy ziemia sławieńska nie należała do księcia świeckiego. Potwierdzenie dóbr klasztoru nie miało zatem realnego wymiaru, ale podkreślało roszczenia do tego terytorium ${ }^{19}$.

Przejęcie władzy nad całym Pomorzem rozpoczęło proces tworzenia własnej kancelarii przez Mściwoja II, który także na szerszą skalę zaczął wykorzystywać dokument w sprawach wewnętrznych państwa ${ }^{20}$. Średnia roczna liczba dla okresu 1273-1294 na poziomie nieco ponad 6 dokumentów stawia księcia gdańskiego $\mathrm{w}$ gronie najaktywniejszych w tej materii w II poł. XIII wieku dzielnicowych

${ }^{16}$ Literatura dotycząca tego okresu jest bogata i obfituje w najrozmaitsze wnioski. Por. J. Powierski, Układ kamieński (1264) na tle stosunków między książętami pomorskimi, Krzyżakami i Prusami w latach sześćdziesiątych XIII wieku, „Rocznik Olsztyński”, VIII, 1968; K. Jasiński, Pomorsko-krzyżackie układy pokojowe z 1267 i 1268 roku, „Zapiski Historyczne”, XLVII, 1982, z. 4; tenże, Wojna domowa na Pomorzu ...; tenże, List Mściwoja II...; G. Labuda, Pomorsko-krzyżacki zatarg graniczny z roku 1267/1268. Przyczynek do migracji Prusów na Pomorze Gdańskie, „Zapiski Historyczne”, L, 1985, z. 2; B. Śliwiński, Rola polityczna rycerstwa gdańskiego w okresie wojny domowej na Pomorzu Gdańskim w latach 1269-1271, „Zapiski Historyczne”, LI, 1986, z. 2; tenże, Pogranicze kujawsko-pomorskie w XII-XIII wieku. Z dziejów Bydgoskiego i Wyszogrodzkiego w latach 1113-1296, Warszawa-Poznań 1989, s. 163-165; tenże, Jeszcze w sprawie układów pomorsko-krzyżackich z roku 1267/1268, „Zapiski Historyczne”, LVII, 1992, z. 2-3; tenże, Układ księcia wschodniopomorskiego..., s. 129-139.

${ }^{17}$ PllUB, nr 238 (1269 r.), 250 (1271 r., list), 225 (1268 r.). Zob. K. Jasiński, List Mściwoja II...; J. Powierski, Układ kamieński (1264)...; B. Śliwiński, Rola polityczna możnowładztwa ..., s. 63-64; tenże, Jeszcze w sprawie układów...; tenże, Układ księcia wschodniopomorskiego Mściwoja II...

${ }^{18}$ PllUB, nr 251 (1271 r.). Por. J. Spors, Podziały administracyjne..., s. 291-293; K. Jasiński, Wojna domowa..., s. 151-155.

${ }^{19}$ PllUB, nr 239. J. Spors, Dzieje polityczne ziemi sławieńskiej, słupskiej i białogardzkiej XIIXIV w., Poznań-Słupsk 1973, s. 121-123.

${ }^{20}$ A. Gut, Średniowieczna dyplomatyka wschodniopomorska..., s. 130-135. 
książąt polskich ${ }^{21}$. Od czasu panowania Mściwoja II wzrastało także w ogóle znaczenie i rola dokumentu na Pomorzu Wschodnim ${ }^{22}$. Uwagę przyciąga zatem w tym okresie rok 1278, w którym Mściwój wystawił tylko dwa dokumenty. Trudno wyjaśnić racjonalnie ten jednorazowy spadek. Raczej nie miała na to wpływu krótka wyprawa zbrojna do Nowej Marchii ${ }^{23}$, ponieważ w następnych latach żadne burzliwe wydarzenia polityczne nie wpływały już w szczególny sposób na ograniczenie działalności kancelaryjnej. Być może zatem obniżenie ilości dokumentów było wynikiem sytuacji przypadkowej, wynikającej chociażby z zaginięcia dokumentów wystawionych w tymże roku czy po prostu z chwilowego braku potrzeby ich wystawiania.

Ponadprzeciętna aktywność wiązała się natomiast także z wydarzeniami politycznymi. W latach 1282-1283 wpłynął na nią spór toczący się z krzyżakami m.in. o ziemię gniewską. Spór zakończył się 18 maja 1282 roku w Miliczu ugodą zapośredniczoną przez legata papieskiego, Filipa z Fermo ${ }^{24}$. Na jej mocy Mściwój II musiał oddać krzyżakom wspomnianą ziemię, która dotąd należała do cystersów z Oliwy, oraz inne części ziem pomorskich, a także zobowiązał się uwolnić je od dziesięciny i innych właścicieli ${ }^{25}$. Realizacja tych postanowień wymagała zatem porozumień z dawnymi posiadaczami oddanych ziem - głównie z Oliwą - i z biskupem włocławskim, w którego dyspozycji znajdowała się dziesięcina. Już w październiku 1282 roku książę wystawił trzy dokumenty dla biskupa Albierza, związane z odszkodowaniem za zrzeczenie się dziesięcin z ziemi gniewskiej, a w listopadzie tego samego roku za odstąpione zakonowi ziemie nad Olszycą i Barsznicą nadał norbertankom żukowskim jaz na rzece Łebie ${ }^{26}$, co Krystyna Zielińska uznała za przygotowanie do realizacji ugody przez stronę pomorską ${ }^{27}$. Kolejne działania w tej sprawie podjął Mściwój w 1283 roku na zjaz-

${ }^{21}$ Chodzi o Przemysła II (średnio ok. 9 dok.) i Henryka Probusa (prawie 7 dok.). Zob. tamże, s. 77, zwłaszcza przypis 77 .

22 Tamże, s. 230-240.

${ }^{23}$ W. Rubczyński, Wielkopolska pod rzadami synów Władysława Odonicza (1239-1279), „Rocznik Filarecki”, 1, 1886, s. 317-318; S. Kujot, Dzieje Prus Królewskich, cz. 1: Do 1309 r., „Roczniki Towarzystwa Naukowego w Toruniu”, 22, 1915, s. 994.

${ }^{24}$ PllUB, nr 336, 337.

${ }^{25}$ K. Zielińska, Zjednoczenie Pomorza Gdańskiego z Wielkopolska pod koniec XIII w. Umowa kępińska 1282 r., Toruń 1968, s. 86-87.

${ }^{26}$ PllUB, nr 341, 342, 343, 345.

${ }^{27}$ K. Zielińska, Zjednoczenie..., s. 89. 
dach w Gdańsku (marzec) i w Świeciu (lipiec). W Gdańsku książę oficjalnie przekazał ziemię gniewską, nadał Oliwie 16 wsi w okolicach tego miasta w zamian za majątki utracone w ziemi gniewskiej i obiecał uzyskać dla nich zwolnienie z dziesięciny. Całość zwieńczyła generalna konfirmacja dóbr i uprawnień cystersów oliwskich. Mściwój wystawił wówczas cztery dokumenty, a jeżeli dodać, że dokument dla krzyżaków został wydany w trzech ekspedycjach, to nawet sześćc ${ }^{28}$, a zatem tyle, co przeciętnie w ciągu jednego roku. W Świeciu natomiast podjęto rokowania z biskupem Albierzem na temat rezygnacji z dziesięcin. W związku z tym faktem książę wydał kolejne cztery dokumenty i w dwóch ekspedycjach jeszcze raz potwierdził krzyżakom prawa do przekazanych im ziem ${ }^{29}$. Realizacja ugody milickiej przy pomocy dokumentów wynikała w głównej mierze $\mathrm{z}$ faktu, że wszystkie zainteresowane strony: krzyżacy, cystersi, norbertanki, biskup włocławski należeli do stanu duchownego. Sam spór toczył się przed sądem kościelnym, a ponieważ realizacja postanowień ugody przedłużała się, krzyżacy interweniowali w 1282 roku u papieża ${ }^{30}$. Udział stron duchownych i zaangażowanie w spór sądów kościelnych wzmagały potrzebę utrwalenia działań prawnych na piśmie, jako że dla prawa kanonicznego dokument był już najważniejszym środkiem dowodowym.

Kolejne wzrosty w latach 1284, 1290 i 1294 miały już jednak związek jak się wydaje - przede wszystkim z uświadomieniem na dworze Mściwoja II roli dokumentu. Widać to wyraźnie w 1290 roku, w którym ponad połowę wystawionych dokumentów stanowią nadania spisane dla rycerstwa ${ }^{31}$. W innym miejscu wskazywano na to, że Mściwój wykorzystywał dokument w polityce wewnętrznej jako rodzaj środka politycznej propagandy w stosunku do rycerstwa $^{32}$. A przełom lat 80 . i 90. wymagał od władcy wschodniopomorskiego szczególnych zabiegów. Kumulacja dokumentów w 1290 roku mogła wynikać z faktu, że w tym właśnie czasie Mściwój starał się u swego możnowładztwa o uznanie umowy sukcesyjnej zawartej w 1287 roku w Słupsku pomiędzy księciem wschodniopomorskim, księciem wielkopolskim, Przemysłem II i księciem

\footnotetext{
${ }^{28}$ PlIUB, nr 351 (trzy ekspedycje), 353, 355, 358.

${ }^{29}$ Tamże, nr 362, 363, 364, 365, 368 (dwie ekspedycje). P. Kriedte, Die Herrschaft der Bischöfe von Wtoctawek in Pommerellen von den Anfängen bis zum Jahre 1409, Göttingen 1974, s. 106-113.

${ }^{30}$ M. Grzegorz, Komturstwo gniewskie i jego strategiczne znaczenie, Bydgoszcz 2003, s. 108.

${ }^{31}$ PllUB, nr 463, 466, 313, 472, 473, 475.

${ }^{32}$ A. Gut, Średniowieczna dyplomatyka wschodniopomorska..., s. 231-232.
} 
zachodniopomorskim, Bogusławem IV, która została potwierdzona na zjeździe w Nakle, być może w 1291 roku $^{33}$. Rok 1294 przyniósł z kolei więcej dokumentów z podobnych przyczyn. Ze względu na zbliżający się koniec życia Mściwój dokonywał ostatnich nadań, a świadomi tego odbiorcy zapewne bardziej zabiegali o potwierdzenie tych prawnych czynności na piśmie.

\section{Rytm miesięczny i tygodniowy}

Do analizy rytmu miesięcznego i tygodniowego dysponujemy mniejszą liczbą dokumentów, co wynika przede wszystkim z faktu, że znaczna część dokumentów Mściwoja II posiadała w datacji jedynie rok $^{34}$. Takich dyplomów zachowało się 32, co daje 22\% wszystkich dokumentów Mściwoja jedynie z datacją roczną. Ten brak pełnej datacji wydaje się przy tym być jakimś efektem pracy w kancelarii księcia wschodniopomorskiego, a nie ogólnej tendencji w dyplomatyce książęcej tego okresu. Lepiej zorganizowana kancelaria księcia wielkopolskiego Przemysła II, działająca w podobnym okresie, także wystawiała dokumenty bez daty dziennej, ale było ich tylko ok. 14\%35. W zachodniopomorskiej kancelarii Bogusława IV w okresie od 1278 do 1295 roku (podział księstwa) takich dyplomów wystawiono tylko niecałe $5 \%{ }^{36}$. Warto przy tym zauważyć, że dosyć duża ilość takich dokumentów wystawiona została przez Mściwoja II dla rycerstwa ${ }^{37}$. Jeśli dodać do tego trzy znane przypadki zdecydowanie późniejszego wystawienia dokumentu niż data czynności prawnej ${ }^{38}$, można stwierdzić, że wiele z dyplomów Mściwoja II (zwłaszcza dla rycerstwa) wystawionych zostało jakiś czas później

${ }^{33}$ J. Bieniak, Postanowienia układu kępińskiego (15 lutego 1282), „Przegląd Historyczny”, LXXXII, 1991, z. 2, s. 223-229; B. Śliwiński, Rola polityczna możnowładztwa..., s. 184-190.

${ }^{34}$ PllUB, nr 245, 248, 273, 274, 275, 276, 283, 300, 301, 330, 331, 349, 350, 369, 371, 374, 384 , $399,400,415,416,435,444,474,483,492,493,503,504,509,511,519$.

${ }^{35}$ Wyliczenia własne na podstawie Kodeks Dyplomatyczny Wielkopolski, t. I-IV, wyd. I. Zakrzewski, Poznań 1877-1881; t. VI, wyd. A. Gąsiorowski, H. Kowalewicz, Warszawa-Poznań 1982; t. XI, wyd. A. Gąsiorowski, T. Jasiński, T. Jurek, I. Skierska, Poznań 1999. Uwzględniono przy tym uwagi S. Krzyżanowskiego, Dyplomy i kancelaryja Przemysła II. Studyjum z dyplomatyki polskiej XIII wieku, Pamiętnik Akademii Umiejętności, Wydział Filologiczny i Historyczno-Filozoficzny, t. VIII, 1890 oraz J. Pakulskiego, Itinerarium książęco-królewskie Przemysła II, „Studia Źródłoznawcze”, 39, 2001.

${ }^{36}$ Wyliczenia własne na podstawie Pommersches Urkundenbuch, Bd. II-III, bearb. v. R. Prümers, Stettin 1881-1891; Bd. VI, bearb. v. O. Heinemann, Stettin 1906-1907.

${ }^{37}$ PllUB, nr 283, 331, 349, 369, 374, 416, 435, 493, 519.

${ }^{38}$ PllUB, nr 214, 286, 313. Zob. A. Gut, Średniowieczna dyplomatyka wschodniopomorska..., s. 27-28, 232-233 oraz Aneks I, nr 33. 
niż miały miejsce same nadania. O ile w przypadku dokumentów zawierających sam rok, porównanie świadków i datacji zdaje się wskazywać, że rok jest rokiem wystawienia dokumentu, o tyle w wymienionych wyżej trzech przypadkach datacja odnosi się raczej do czynności prawnej ${ }^{39}$. Rok spisania tych dyplomów można wprawdzie bliżej określić (dlatego uwzględniono je w wyliczeniach rocznych), ale cała datacja - w tym data dzienna - odnosi się raczej do działań prawnych. Dlatego też nie zostały one uwzględnione w badaniu. Podobnie jak dokument fundacyjny dla cystersów datowany na styczeń 1274 roku, który albo powstał później i został antydatowany, albo sporządzony został jako koncept i opieczętowany później ${ }^{40}$. W każdym razie datacja także nie odnosi się do czasu spisania. W przypadku analizy dnia w tygodniu do wspomnianych wyżej przypadków doliczyć trzeba jeszcze dwa dokumenty, w których podany był wyłącznie okres oktawy po święcie i z tego powodu również je należy wykluczyćc ${ }^{41}$.

Tabela 1. Liczba dokumentów Mściwoja II w poszczególnych miesiącach ${ }^{42}$

\begin{tabular}{|c|c|c|c|c|c|c|c|c|c|c|c|c|c|}
\cline { 2 - 16 } \multicolumn{1}{c|}{} & \multicolumn{10}{c|}{ Liczba dokumentów w miesiącach } \\
\cline { 2 - 15 } & ogółem & I & II & III & IV & V & VI & VII & VIII & IX & X & XI & XII \\
\hline 1.b. & 107 & 7 & 8 & 10 & 12 & 9 & 13 & 11 & 4 & 14 & 7 & 6 & 6 \\
\hline$\%$ & 100 & 6,5 & 7,5 & 9,4 & 11,2 & 8,4 & 12,2 & 10,3 & 3,7 & 13,1 & 6,5 & 5,6 & 5,6 \\
\hline
\end{tabular}

Źródło: obliczenia własne.

W tabeli nr 1 przedstawiono liczbę dokumentów Mściwoja wystawianych w poszczególnych miesiącach. Jak widać, dokumenty wystawiane były we wszystkich miesiącach, choć nie oznacza to, że co roku w każdym miesiącu

\footnotetext{
${ }^{39}$ Por. uwagi S. Kętrzyńskiego, O elementach chronologicznych dokumentów Kazimierza Wielkiego, Rozprawy Akademii Umiejętności, Wydział Historyczno-Filozoficzny, Seria II, t. 31, 1914, s. 121: ,jeżeli trzeba było czasami z braku czasu i sił odłożyć spisanie pewnego aktu na później, to łatwo mogło się zdarzyć, że w kancelarii następnie brakowało dostatecznych danych do określenia bądź elementów chronologicznych, bądź geograficznych, bądź wreszcie wśród świadków akcji”.

${ }^{40}$ PllUB, nr 260; K. Bruski, Ziemie nad dolna Wierzyca od XIII do początku XV wieku, Gdańsk 1997, s. 53; A. Gut, Falsyfikaty pelplińskie do 1309 r., w: Kaci, święci, templariusze..., s. 102-105.

${ }^{41}$ PllUB, nr 315, 341.

${ }^{42}$ Przy opracowaniu tabeli wykorzystano statystyczną metodę liczenia sezonowości zjawisk w badaniach historycznych stosowaną najczęściej przez demografów, analizujących ruch naturalny ludności. W pierwszej części tabeli podano rzeczywistą liczbę dokumentów. Natomiast w części drugiej - ze względu na różną długość poszczególnych miesięcy - podano liczbę dokumentów standaryzowaną do długości miesiąca 30-dniowego. Część trzecia z kolei przedstawia wskaźnik sezonowości, będący bezwzględną miarą zjawiska, nadającą się do porównań.
} 
wystawiany był dokument. Ale jest to kwestia zrozumiała, jeśli weźmiemy pod uwagę niewielką ilość dokumentów wystawianych rocznie. Z tabeli wynika jednak jednoznacznie, że kancelaria księcia działała w sposób permanentny, związany z książęcymi objazdami kraju ${ }^{43}$.

Stała działalność kancelaryjna nie wyklucza jednak jej sezonowych wahań. W przypadku Mściwoja II najwięcej dokumentów spisano we wrześniu, czerwcu, kwietniu i lipcu, nieco mniej - w pozostałych miesiącach. Różnice pomiędzy poszczególnymi miesiącami nie wydają się jednak szczególnie duże, może poza sierpniem, w którym w ciągu prawie 30 lat panowania Mściwoja II wystawiono tylko 4 dokumenty. Jeżeli jednak zestawić ze sobą dwa większe podokresy - półrocza - to zróżnicowanie aktywności kancelaryjnej staje się bardziej wyraźne. Okazuje się bowiem, że w półroczu jesienno-zimowym wystawiono 44 dokumenty, czyli nieco ponad $41 \%$, a w półroczu wiosenno-letnim - 63, czyli prawie $59 \%$ wszystkich dokumentów z pełną datacją. Wydaje się zatem, że można mówić o wpływie warunków atmosferycznych (pogodowych), które ograniczając ruchliwość dworu, ograniczały równocześnie częstotliwość wydawania dyplomów ${ }^{44}$.

Sezonowość działań kancelaryjnych może mieć również związek z przebiegiem kościelnego roku liturgicznego. Istotną rolę w początkowym okresie funkcjonowania dokumentu odgrywał bowiem rytuał przekazania go odbiorcy podczas publicznych uroczystości, które wiązały się z celebracją świąt kościelnych, zwłaszcza świąt nakazanych (choć zapewne większe znaczenie prawne miało publiczne dokonanie czynności prawnej). Nie licząc niedziel, świąt takich w ciągu roku było kilkadziesiąt, a do najważniejszych należały święta Pańskie (Wielkanoc, Wniebowstąpienie, Zesłanie Ducha Świętego, Boże Narodzenie, Obrzezanie, Epifania, Znalezienie Krzyża, Podwyższenie Krzyża, od 1264 r. również Boże Ciało), święta maryjne (Oczyszczenie, Zwiastowanie, Wniebowzięcie,

${ }^{43}$ Z. Górski, Itinerarium Mszczuja II (1264-1294), Acta Universitatis Nicolai Copernici, Historia VIII, Nauki Humanistyczno-Społeczne, z. 54, 1973, s. 55-71.

${ }^{44}$ Podobną prawidłowość zaobserwować można również w kancelarii książąt: zachodniopomorskiego, Bogusława IV, i wielkopolskiego, Przemysła II. W obu przypadkach różnice między obu półroczami nie są jednak tak wyraźne. Z pobieżnych wyliczeń wynika bowiem, że u Bogusława w półroczu jesienno-zimowym wystawiono 45,5\% dokumentów, we wiosenno-letnim $54,4 \%$, u Przemysła II - odpowiednio 47\% i 53\%. Na wyrywkowym materiale podobną prawidłowość zaobserwował także I. Hlavaček w kancelarii Jana Luksemburskiego. Jednak w kancelarii Przemysła Ottokara II przewagę zyskują miesiące jesienno-zimowe (Zur Frage der Saisonalität..., s. 453-454). 
Narodzenie), święta apostołów i ewangelistów oraz św. Pawła, a także - w przypadku polskim - św. Wojciecha i św. Stanisława ${ }^{45}$.

Zestawiając dokumenty Mściwoja II o pełnej datacji z terminami świąt nakazanych, zauważyć można, że ponad połowa z nich datowana jest na dni znajdujące się w pobliżu najważniejszych nieruchomych świąt nakazanych ${ }^{46}$. Najwięcej zatem z nich sporządzono w pobliżu takich świąt, jak: św. św. Piotra i Pawła ${ }^{47}$, św. Jakuba apostoła ${ }^{48}$, św. Mateusza apostoła i ewangelisty ${ }^{49}$, Narodzenie NMP ${ }^{50}$, Michała Archanioła ${ }^{51}$ czy Młodzianków ${ }^{52}$. Po trzy dokumenty datowane są na okres świąt Jana Chrzciciela ${ }^{53}$, biskupa Marcina ${ }^{54}$ i św. Wojciecha ${ }^{55}$, po dwa - na święto św. Bartłomieja apostoła i św. biskupa Stanisława ${ }^{56}$. Nie we wszystkich tych przypadkach w sposób bezpośredni odwoływano się jednak do święta nakazanego, czasami wybierano bowiem do datacji inne święto ${ }^{57}$. Jak słusznie zauważył przy tym Zbigniew Górski, nie można zaobserwować związku pomiędzy datą wystawienia a miejscem wystawienia (lokalny kult świętych) czy odbiorcą

${ }^{45}$ I. Skierska, Sabbatha sanctifices. Dzień święty w średniowiecznej Polsce, Warszawa 2008, s. 121, 127-128, 139-146.

${ }^{46}$ Zestawiono terminy przypadające na okres od kilku dni przed świętem do jego oktawy.

${ }^{47}$ PllUB, nr 291, 308, 339, 372, 434, 485.

48 Tamże, nr 363-365, 368, 373.

49 Tamże, nr 271, 378, 381; Zdrenka.

${ }^{50}$ Tamże, nr 256, 257, 267, 375, 499.

${ }^{51}$ Tamże, nr 258, 341, 487, 488, 515.

${ }^{52}$ Tamże, nr 318, 319, 401-403.

${ }^{53}$ Tamże, nr 289, 453; Zielińska.

54 Tamże, nr 327, 346, 491.

${ }^{55}$ Tamże, nr 421, 449, 466.

${ }^{56}$ Tamże, nr 437, 438, 394, 452.

${ }^{57}$ Kalendarz świąt nieruchomych stosowanych w dokumentach Mściwoja II zestawia Z. Górski, Oznaczanie dnia w dokumentach książą Pomorza Gdańskiego, Bydgoskie Towarzystwo Naukowe, Prace Wydziału Nauk Humanistycznych, Seria C, nr 16, Prace Komisji Historii XI, Warszawa-Poznań 1975, s. 60-62. W dokumentach zauważyć można jakby miejscowy zwyczaj, według którego w datacji wskazywano przede wszystkim na samo święto, jego wigilię lub dzień następny po święcie, ewentualnie na oktawę. Tylko sześć razy odwołano się do dnia tygodnia przed lub po święcie, ale głównie ruchomym (PllUB, nr 238, 438, 464, 507, 259; Zielińska). Por. datację dokumentów PlIUB, nr 258, 259 oraz PllUB, nr 341-343. 
dokumentu (patron zgromadzenia) ${ }^{58}$. Wydaje się zatem, że święta użyte w datacji były raczej wynikiem_przemieszczania się dworu niż świadomego wyboru ze strony odbiorcy czy wystawcy.

Zdecydowanie rzadziej dokumenty wystawiane były przy okazji świąt ruchomych (nie licząc niedziel w okresie zwykłym), jednak i w tym wypadku zaobserwować można pewne ich nagromadzenie w związku z niektórymi wydarzeniami liturgicznymi. Sugeruje to wniosek, że na sezonowość działań prawnych, ale i kancelaryjnych, wpływ mogły mieć także motywy religijne (dewocyjne).

W tym wypadku najpierw trzeba zwrócić uwagę na dwa okresy postne w ciągu roku - Wielki Post i Adwent. Zimowy Adwent przynosi przy tym niewielką liczbę dokumentów, bo zaledwie trzy ${ }^{59}$. W okresie wielkopostnym (wliczając w to także jeden dokument z Przedpościa) wystawiono natomiast już 15 dokumentów, czyli 14\% wszystkich dokumentów Mściwoja II z pełną datacją ${ }^{60}$. Najwięcej wystawiono ich w okolicy niedzieli Invocavit, ponieważ aż cztery powstały w wyniku zjazdu gdańskiego w sprawie ziemi gniewskiej w 1283 roku, który zapewne odbywał się na początku Wielkiego Postu.

Kolejna kwestia to związek czasu wystawienia z dwoma najważniejszymi świętami Pańskimi - Bożym Narodzeniem i Wielkanocą. I tu okazuje się, że powiązanie istnieje. Podkreślić należy przy tym, że nie ma dokumentów datowanych bezpośrednio na oba święta, ale istnieje pewne ich nagromadzenie w czasie najbliższym po nich. O ile bowiem przed Bożym Narodzeniem dokumentów było niewiele, to już po tym święcie - licząc do oktawy Epifanii - powstało ich dziewięćć $^{61}$. W okresie po Wielkanocy z kolei w dokumenty obfituje czas najbliższy Niedzieli Przewodniej, w którym wystawiono jednak tylko pięć dokumentów ${ }^{62}$.

Ze świętowaniem wiąże się również rytm pracy kancelaryjnej w ciągu tygodnia, przynajmniej na dworze Mściwoja II. Jednym z najważniejszych nakazanych świąt Pańskich jest bowiem niedziela - dzień, w którym obowiązywał zakaz

${ }^{58}$ Z. Górski, Oznaczanie..., s. 65. H.M. Schaller (Der Heilige Tag als Termin mittelalterlicher Staatsakte, „Deutsches Archiv für Erforschung des Mittelalters”, 30, 1974, s. 12) podaje przykłady takiego związku, ale zaznacza, że były to sytuacje wyjątkowe.

${ }^{59}$ PllUB, nr 329, 501, 502.

${ }^{60}$ PllUB, nr 264, 333, 351, 353, 355, 358, 360 (tu Wielki Piątek), 370, 389, 405, 447, 463, 477, 507, 417 (tu dzień po Siedemdziesiątnicy).

${ }^{61}$ PllUB, nr 225, 263, 318, 319, 401-403, 443, 462.

${ }^{62}$ PllUB, nr 465 (oktawa Wielkanocy), 464 (sobota przed oktawą), 238 (poniedziałek po oktawie), 420, 478 (wtorek po oktawie). 
prac, choć - jak pokazują badania - nie koniecznie przestrzegany ${ }^{63}$. W datacji dokumentów Mściwoja II niedziela nie jest, co prawda, najczęściej występującym dniem tygodnia (tab. 2), ale należy jednak - razem z poniedziałkiem i piątkiem do dni, na które datowano największą liczbę książęcych dokumentów. Ustępuje jedynie wspomnianemu wyżej poniedziałkowi.

Tabela 2. Liczba dokumentów Mściwoja II w ciągu tygodnia

\begin{tabular}{|c|c|c|c|c|c|c|c|c|}
\cline { 2 - 9 } \multicolumn{1}{c|}{} & \multicolumn{7}{c|}{ Liczba dokumentów w poszczególnych dniach tygodnia } \\
\cline { 2 - 9 } & ogółem & niedziela & poniedziałek & wtorek & środa & czwartek & piątek & sobota \\
\hline 1.b. & 105 & 19 & 26 & 14 & 9 & 9 & 15 & 13 \\
\hline$\%$ & 100 & 18,1 & 24,7 & 13,3 & 8,6 & 8,6 & 14,3 & 12,4 \\
\hline
\end{tabular}

Źródło: opracowanie własne.

Patrząc na powyższą tabelę, odnosi się wrażenie jakby - permanentnie przecież działająca - kancelaria Mściwoja II do intensywniejszej pracy przystępowała w piątek i kończyła ją jeszcze we wtorek. Można byłoby wysnuć z tego wniosek, że terminy te wiążą się z niedzielną publikacją czynności prawnej. Nadania dokonane i spisane w piątek i sobotę ogłaszano publicznie w niedzielę, nadania dokonane w niedzielę spisywano w tym samym dniu, ale najczęściej jednak w poniedziałek.

Porównanie z innymi kancelariami - zachodniopomorskiego Bogusława IV (do 1295 r.) i wielkopolskiego Przemysła II (tab. 3) - pokazuje, że taki rozkład aktywności kancelaryjnej w tygodniu nie był jednak powszechny. U Mściwoja bowiem najczęstszym dniem występującym w datacji był poniedziałek, po którym następował spadek aktywności wzrastający dopiero pod koniec tygodnia. W kancelarii Bogusława IV zaś wzrost aktywności zaczynał się w środę, a jej kulminacja przypadała na niedzielę. W kancelarii Przemysła II natomiast sezonowość tygodniowa jest w ogóle słabo zauważalna. Najwięcej dokumentów datowanych było, co prawda, także na niedzielę, ale w pozostałych dniach tygodnia aktywność kancelaryjna była niewiele niższa. Zestawienie to wskazuje, że rytm pracy

${ }^{63}$ Np. I. Skierska, Sabbatha sanctifices...; A. Gąsiorowski, I. Skierska, Targ w czasie zakazanym. Średniowieczna norma i praktyka, w: Kościót. Kultura. Społeczeństwo. Studia z dziejów średniowiecza i czasów nowożytnych, red. S. Bylina i in., Warszawa 2000, s. 229-235; A. Bartoszewicz, Czas w małych miastach. Studium z dziejów kultury umysłowej późnośredniowiecznej Polski, Warszawa-Pułtusk 2003, s. 206-219. 
Tabela 3. Dzień tygodnia w datacji dokumentów Mściwoja II, Bogusława IV i Przemysła II

\begin{tabular}{|l|c|c|c|c|c|c|}
\hline \multirow{3}{*}{ Dzień tygodnia } & \multicolumn{6}{|c|}{ Wystawca } \\
\cline { 2 - 7 } & \multicolumn{2}{|c|}{ Mściwój II } & \multicolumn{2}{c|}{ Bogusław IV } & \multicolumn{2}{c|}{ Przemysł II } \\
\cline { 2 - 7 } & $1 . b$. & $\%$ & $1 . b$. & $\%$ & $1 . b$. & $\%$ \\
\hline Niedziela & 19 & 18,1 & 30 & 20,1 & 26 & 17,1 \\
\hline Poniedziałek & 26 & 24,7 & 12 & 8,0 & 16 & 10,5 \\
\hline Wtorek & 14 & 13,3 & 11 & 7,4 & 25 & 16,5 \\
\hline Środa & 9 & 8,6 & 25 & 16,8 & 22 & 14,5 \\
\hline Czwartek & 9 & 8,6 & 20 & 13,4 & 16 & 10,5 \\
\hline Piątek & 15 & 14,3 & 26 & 17,5 & 23 & 15,1 \\
\hline Sobota & 13 & 12,4 & 25 & 16,8 & 24 & 15,8 \\
\hline & & & & & & \\
\hline \multicolumn{1}{|c|}{ Ogółem } & 105 & 100 & 149 & 100 & 152 & 100 \\
\hline
\end{tabular}

Źródło: opracowanie własne.

w ciągu tygodnia był raczej efektem zwyczajów kancelaryjnych poszczególnych dworów, choć w pewnej mierze wiązał się z momentem publikacji czynności prawnej, która zapewne najczęściej przypadała w niedzielę.

\section{Podsumowanie}

Przeprowadzona w artykule analiza rytmu pracy kancelarii Mściwoja II pokazuje, że - jak wszystkie średniowieczne kancelarie - działała ona w sposób permanentny. Zauważyć w niej jednak można pewne wahania cyklicznie i sezonowe, które ukazują specyfikę pracy kancelaryjnej na dworze ostatniego z Sobiesławiców.

W przypadku cykli rocznych zaobserwować można przede wszystkim bardzo małą ilość dokumentów wystawianych do 1273 roku, pozostającą na poziomie z czasów Świętopełka, ojca Mściwoja II. Jednak od roku 1273, kiedy ustabilizowała się sytuacja polityczna w księstwie, kiedy książę objął władzę nad całym dziedzictwem ojca i rozpoczął skutecznie realizować własną koncepcję zarządzania państwem, liczba wystawianych dokumentów wzrosła i ustabilizowała się na poziomie 4-7 w roku. Zmiana ta wiązała się głównie z postępującym w czasach Mściwoja procesem umacniania prawnej roli dokumentu jako środka dowodowego czy środka realizacji zamierzeń politycznych. W okresie tym pojawiały się jednak pewne ponadprzeciętne lata, w których wystawiono zdecydowanie więcej dyplomów. Wzrosty wynikały z aktualnych potrzeb w prowadzeniu albo polityki zewnętrznej (spór przed sądem kościelnym z zakonem krzyżackim), 
albo polityki wewnętrznej (zabiegi o pozyskanie możnowładztwa dla akceptacji umowy sukcesyjnej).

Analiza rytmu pracy w ciągu roku pokazała natomiast istnienie pewnych wahań sezonowych, wywołanych wpływem pór roku. Mniej dokumentów wystawiono bowiem w półroczu jesienno-zimowym, co miało zapewne związek z warunkami pogodowymi, ograniczającymi ruchliwość książęcego dworu oraz odbiorców zabiegających o dyplomy. W ciągu roku dokumenty kumulowały się również wokół dat świąt kościelnych. Były to przede wszystkim święta nieruchome: św. św. Piotra i Pawła, Jakuba apostoła, Mateusza apostoła i ewangelisty, Narodzenia NMP, Michała Archanioła i Młodzianków. Nie istnieją natomiast dokumenty, które byłyby wystawione w najważniejsze święta chrześcijańskie Boże Narodzenie i Wielkanoc. Inaczej natomiast wyglądała sytuacja z okresami poprzedzającymi te święta i następującymi po nich. O ile w zimowym Adwencie dokumenty były bardzo rzadkie, to w czasie po Bożym Narodzeniu - od Młodzianków aż do oktawy Epifanii - następuje ich kumulacja. Inaczej natomiast przedstawia się sytuacja ze świętem Zmartwychwstania. W tym przypadku poprzedzający święto okres Wielkiego Postu obfituje w dokumenty (14\% wszystkich dokumentów Mściwoja II), podczas gdy w czasie bezpośrednio po Wielkanocy wystawiono ich bardzo mało. Kalendarz liturgiczny miał zatem również wpływ na sezonowość rytmu pracy w ciągu roku. Istnieje również prawdopodobieństwo, że wpływał on na działania kancelaryjne w ciągu tygodnia. Najwięcej dokumentów datowanych jest bowiem na poniedziałek, co może wynikać z faktu, że tego dnia spisywano czynności prawne opublikowane uroczyście podczas niedzielnej Mszy Św. Datacja wielu dokumentów opiewa również na samą niedzielę, a także na piątek, co także wskazywać może na związek z uroczystym wręczeniem dyplomu w dniu Pańskim.

\section{Bibliografia}

\section{Źródła}

Kodeks Dyplomatyczny Wielkopolski, t. I-IV, wyd. I. Zakrzewski, Poznań 1877-1881; t. VI, wyd. A. Gąsiorowski, H. Kowalewicz, Warszawa-Poznań 1982; t. XI, wyd. A. Gąsiorowski, T. Jasiński, T. Jurek, I. Skierska, Poznań 1999.

Pommerellisches Urkundenbuch, hrsg. v. M. Perlbach, Danzig 1882.

Pommersches Urkundenbuch, Bd. II-III, bearb. v. R. Prümers, Stettin 1881-1891; Bd. VI, bearb. v. O. Heinemann, Stettin 1906-1907. 
Zdrenka J., Nieznany dokument Mściwoja II z roku 1274?, w: Personae, colligationes, facta. Profesorowi Kazimierzowi Jasińskiemu w 70. rocznicę urodzin przyjaciele, koledzy, uczniowie, red. J. Bieniak i in., Toruń 1991, s. 283-284.

Zielińska K., Przywilej Mszczuja II z 1277 r. dla kasztelana puckiego Czcibora, Zeszyty Naukowe UMK w Toruniu, Nauki Humanistyczno-Społeczne, z. 354, Historia V, 1969, s. 16-19.

\section{Opracowania}

Bartoszewicz A., Czas w matych miastach. Studium z dziejów kultury umysłowej późnośredniowiecznej Polski, Warszawa-Pułtusk 2003.

Bieniak J., Postanowienia układu kępińskiego (15 lutego 1282), „Przegląd Historyczny”, LXXXII, 1991, z. 2, s. 223-229.

Bruski K., Ziemie nad dolna Wierzyca od XIII do poczatku XV wieku, Gdańsk 1997.

Gąsiorowski A., Skierska I., Targ w czasie zakazanym. Średniowieczna norma i praktyka, w: Kościót. Kultura. Społeczeństwo. Studia z dziejów średniowiecza i czasów nowożytnych, red. S. Bylina i in., Warszawa 2000.

Górski Z., Itinerarium Mszczuja II (1264-1294), „Acta Universitatis Nicolai Copernici Nauki Humanistyczno-Społeczne. Historia", 8, 1973, z. 54.

Górski Z., Oznaczanie dnia w dokumentach książat Pomorza Gdańskiego, Bydgoskie Towarzystwo Naukowe, Prace Wydziału Nauk Humanistycznych, Seria C, nr 16, Prace Komisji Historii XI, Warszawa-Poznań 1975.

Grzegorz M., Komturstwo gniewskie i jego strategiczne znaczenie, Bydgoszcz 2003.

Gut A., Falsyfikaty pelplińskie do 1309 r., w: Kaci, święci, templariusze, red. B. Śliwiński, Malbork 2008 (Studia z dziejów średniowiecza, 14).

Gut A., Średniowieczna dyplomatyka wschodniopomorska. Dokumenty i kancelarie Pomorza Wschodniego do 1309 roku, Szczecin 2014.

Hlavaček I., Zur Frage der Saisonalität und des Arbeitsrhythmus in der mittelalterlichen Verwaltung. Bemerkungen zur Auslaufstatistik der Kanzleien der letzten Přemysliden und Johanns von Luxemburg, w: Homines et societas. Czasy Piastów i Jagiellonów. Studia historyczne ofiarowane Antoniemu Gąsiorowskiemu w 65. rocznice urodzin, red. T. Jasiński, T. Jurek, J.M. Piskorski, Poznań 1997.

Jasiński K., List Mściwoja II do margrabiów brandenburskich. Uwagi polemiczne i postulaty badawcze, w: Pomerania Mediaevalis. Pomorze słowiańskie i jego sasiedzi X-XV wiek, red. J. Hauziński, Gdańsk 1995.

Jasiński K., Pomorsko-krzyżackie układy pokojowe z 1267 i 1268 roku, „Zapiski Historyczne", XLVII, 1982, z. 4.

Jasiński K., Wojna domowa na Pomorzu Gdańskim w latach 1269/70-1272 (ze szczególnym uwzględnieniem roli rycerstwa i możnowładztwa), w: Społeczeństwo Polski Średniowiecznej, t. 3, red. S.K. Kuczyński, Warszawa 1985. 
Kętrzyński S., O elementach chronologicznych dokumentów Kazimierza Wielkiego, Rozprawy Akademii Umiejętności, Wydział Historyczno-Filozoficzny, Seria II, t. 31, 1914.

Kopczyński M., Podstawy statystyki. Podręcznik dla humanistów, Warszawa 2005.

Kriedte P., Die Herrschaft der Bischöfe von Włocławek in Pommerellen von den Anfängen bis zum Jahre 1409, Göttingen 1974.

Krzyżanowski S., Dyplomy i kancelaryja Przemysła II. Studyjum z dyplomatyki polskiej XIII wieku, Pamiętnik Akademii Umiejętności, Wydział Filologiczny i Historyczno-Filozoficzny, t. VIII, 1890.

Kujot S., Dzieje Prus Królewskich, cz. 1: Do 1309 r., „Roczniki Towarzystwa Naukowego w Toruniu", 22, 1915.

Labuda G., Pomorsko-krzyżacki zatarg graniczny z roku 1267/1268. Przyczynek do migracji Prusów na Pomorze Gdańskie, „Zapiski Historyczne”, L, 1985, z. 2.

Lingenberg H., Urkundenfälschungen des Klosters Oliva und anderer geistlicher Institutionen Pommerellens/Pommerns (bis ca. 1310), Lübeck 1996.

Pakulski J., Itinerarium książęco-królewskie Przemysła II, „Studia Źródłoznawcze”, 39, 2001.

Powierski J., Układ kamieński (1264) na tle stosunków między ksiązętami pomorskimi, Krzyżakami i Prusami w latach sześćdziesiątych XIII wieku, „Rocznik Olsztyński”, VIII, 1968.

Problemy nauk pomocniczych historii, t. 5, Katowice 1976.

Rubczyński W., Wielkopolska pod rządami synów Władysława Odonicza (1239-1279), „Rocznik Filarecki”, 1, 1886.

Schaller H.M., Der Heilige Tag als Termin mittelalterlicher Staatsakte, „Deutsches Archiv für Erforschung des Mittelalters”, 30, 1974.

Skierska I., Sabbatha sanctifices. Dzień święty w średniowiecznej Polsce, Warszawa 2008 .

Spors J., Dzieje polityczne ziemi sławieńskiej, stupskiej i białogardzkiej XII-XIV w., Poznań-Słupsk 1973.

Spors J., Podziały administracyjne Pomorza Gdańskiego i Sławieńsko-Stupskiego od XII do poczatku XIV w., Słupsk 1983.

Śliwiński B., Jeszcze w sprawie układów pomorsko-krzyżackich z roku 1267/1268, „Zapiski Historyczne”, LVII, 1992, z. 2-3.

Śliwiński B., Pierwszy przywilej rycerski księcia Mściwoja II. Krytyka autentyczności dokumentu z roku 1266 dla Ścibora z Gacek, „Studia Źródłoznawcze”, XXXIIXXXIII, 1990.

Śliwiński B., Pogranicze kujawsko-pomorskie w XII-XIII wieku. Z dziejów Bydgoskiego i Wyszogrodzkiego w latach 1113-1296, Warszawa-Poznań 1989. 
Śliwiński B., Rola polityczna możnowładztwa na Pomorzu Gdańskim w czasach Mściwoja II, Zeszyty Naukowe Uniwersytetu Gdańskiego, Rozprawy i monografie, nr 86, Gdańsk 1987.

Śliwiński B., Rola polityczna rycerstwa gdańskiego w okresie wojny domowej na Pomorzu Gdańskim w latach 1269-1271, „Zapiski Historyczne”, LI, 1986, z. 2.

Śliwiński B., Układ księcia wschodniopomorskiego Mściwoja II z margrabiami brandenburskimi w Choszcznie w 1269 r. Powrót problemu, w: Mieszczanie, wasale, zakonnicy, red. B. Śliwiński, Malbork 2004 (Studia z dziejów średniowiecza, 10).

Zielińska K., Zjednoczenie Pomorza Gdańskiego z Wielkopolska pod koniec XIII w. Umowa kępińska 1282 r., Toruń 1968.

\section{STRESZCZENIE}

W artykule prześledzono roczną ilość wystawianych dokumentów, a także ilość dokumentów wydawanych w poszczególnych miesiącach oraz dniach tygodnia w XIII-wiecznej kancelarii księcia wschodniopomorskiego, Mściwoja II. Dane te poddano analizie statystycznej, próbując wychwycić istnienie wahań cyklicznych i sezonowych w rytmie pracy tej kancelarii.

Otrzymane wyniki pokazują, że - jak wszystkie średniowieczne kancelarie - kancelaria Mściwoja II działała w sposób permanentny. Zauważyć w niej jednak można pewne wahania cyklicznie i sezonowe, które ukazują specyfikę pracy kancelaryjnej na dworze ostatniego z Sobiesławiców. W przypadku cykli roczny zaobserwowano wzrost ilości wystawianych rocznie dokumentów po roku 1273, co można wiązać z postępującym w czasach Mściwoja procesem umacniania prawnej roli dokumentu jako środka dowodowego czy środka realizacji zamierzeń politycznych. W okresie tym pojawiały się jednak pewne ponadprzeciętne lata, w których wystawiono zdecydowanie więcej dyplomów. Wzrosty wynikały z aktualnych potrzeb w prowadzeniu albo polityki zewnętrznej, albo polityki wewnętrznej. Analiza rytmu pracy w ciągu roku pokazała natomiast istnienie pewnych wahań sezonowych, wywołanych wpływem pór roku, ponieważ mniej dokumentów wystawiono w półroczu jesienno-zimowym. Na sezonowość pracy w ciągu roku wpływ miał również kalendarz liturgiczny, ponieważ datacje dokumentów kumulują się wokół dat niektórych świąt kościelnych, w okresie Wielkiego Postu oraz w czasie po Bożym Narodzeniu. Istnieje również prawdopodobieństwo, że kalendarz liturgiczny wpływał także na działania kancelaryjne w ciągu tygodnia. Najwięcej dokumentów datowanych jest bowiem na poniedziałek, co może wynikać z faktu, że tego dnia spisywano czynności prawne opublikowane uroczyście podczas niedzielnej Mszy Św. Datacja wielu dokumentów opiewa również na samą niedzielę, a także na piątek, co także wskazywać może na związek z uroczystym wręczeniem dyplomu w dniu Pańskim. 


\title{
The Rhythm of Work in the Chancellery \\ OF MŚcIWOJ (MESTWIN) II (1220-1294), \\ an East Pomeranian Duke (1266-1294)
}

\begin{abstract}
The article analyses all the documents issued by the 13th-century chancellery of Mestwin II, an East Pomeranian Duke, year by year, as well as in particular months and days. These data have been processed statistically in order to obtain cyclical and seasonal fluctuations in the rhythm of work in the Chancellery.

The results of the analysis prove that Mestwin's Chancellery, like all the Medieval Chancelleries, generally functioned on a permanent basis. Yet, some cyclical and seasonal fluctuations may be detected, which shows the uniqueness of chancellery work at the court of the last of the Samborides (German: Samboriden, Polish: dynastia Sobiestawiców). What was noticed in the case of the annual cycles was an increase of documents issued each year after 1273, which might be associated with a process, speeded up under Mestwin, of strengthening the legal role of documents as evidential proof or a way to realise political objectives. Yet, that steady process was disrupted in the years in which the number of diplomas issued was decisively higher. Those increases resulted from the current needs of external and internal policies. The analysis of the rhythm of work in particular years indicates some seasonal fluctuations caused by the year's seasons, because fewer documents were issued in autumn and winter. Seasonal fluctuations were also caused by the liturgical calendar, because the dating of documents were cumulated during some ecclesiastical holidays, like Lent or Christmas. It is also probable that the liturgical calendar influenced the chancellery's activity during the week, as the most documents were dated on Monday; it may result from the fact that the legal activities made public during the Sunday's Mass were put down on paper on that day. Many documents were also dated on Sunday, as well as on Friday, which may be connected with the ceremony of diploma handing in on dies Dominicus.
\end{abstract}

